\title{
EL RITUAL DEL DON, UN PARADIGMA EN LA RETÓRICA DE LA PUBLICIDAD. LITERATURA MEDIEVAL Y PUBLICIDAD CONTEMPORÁNEA
}

\author{
M. ${ }^{a}$ Vicenta HERNÁNDEZ ÁLVAREZ \\ Universidad de Salamanca \\ valvarez@usal.es
}

Resumen: El don, el contra-don y el don obligado, ordenan las relaciones religiosas y sociales en la Edad Media. Integrados perfectamente en la cultura y la ideología de la época, funcionan también como un «tipo» narrativo, como un paradigma que estructura la interpretación de la vida y la organización de los relatos. Este paradigma lo recupera la publicidad contemporánea. Aquí trabaja también como un «tipo», como un modelo retórico cuya pertinencia y pragmatismo están suficientemente justificados.

Résumé: Le don, le contre-don et le don contraignant ordonnent les rapports religieux et sociaux au Moyen Âge. Parfaitement intégrés dans la culture et l'idéologie de l'époque ils fonctionnent aussi comme un «type» narratif, comme un paradigme qui structure l'interprétation de la vie et l'organisation des récits. Ce paradigme est récupéré par la publicité contemporaine où il travaille aussi comme un «type», comme un modèle rhétorique dont la pertinence et le pragmatisme sont parfaitement justifiés. 
Palabras clave: Publicidad. Literatura. Edad Media. Paradigma. Don obligado.

Mots clé: Publicité. Littérature. Moyen Âge. Paradigme. Don contraignant.

¿Hasta qué punto es pertinente comparar la estructura y la estética de la publicidad actual con las estrategias comunicativas de propaganda que pone en funcionamiento la literatura medieval, los Cantares de gesta y los romans del siglo XII? ¿Sobre todo con la literatura del siglo XII, por ser éste un período de relativa prosperidad y paz, donde era posible como hoy, al menos para las clases acomodadas, una cultura del ocio?"

Paul Zumthor (1963), quien osó con éxito la aproximación entre un poema de Adan de la Halle y otro de Paul Eluard, al reconocer la oralidad y la teatralidad como características básicas de la literatura medieval, las aparenta, explícitamente, con los mass media modernos. El Cantar de gesta medieval también es un medio de comunicación de masas, un «artículo de feria» que de algún modo tenía que anunciarse y que venderse.

La literatura medieval, como la publicidad contemporánea, es fundamentalmente anónima. Una voz que nos habla (voz en off) y tras la que es muy difícil descubrir al enunciador personal del discurso. Como señala Paul Zumthor, la literatura medieval se expresa a través de una voz social, colectiva, que determina sus estructuras y sus motivos de acuerdo con una cultura establecida. Algo semejante ocurre con la publicidad en nuestros días. Las voces de los anuncios apenas se diferencian entre sí. Una conciencia y una cultura colectivas se expresan, poderosas, impersonales, como un Gran Hermano mediático. Sabemos que tras esas voces están las marcas y sus patrocinadores, las grandes empresas, la economía; pero la voz no deja de ser plural, como en la literatura medieval, literatura de encargo, tras la que están los patrocinadores de ideología, mecenas que pagan, individuos conocidos a veces, con marca, pero representantes siempre de un colectivo ${ }^{2}$.

\footnotetext{
1 Algunos medievalistas han intentado paralelismos semejantes en otros campos. G. Duby (1995) rastrea las semejanzas del arte medieval y del arte del siglo Xx, y señala las coincidencias en los niveles de la psicología, de las convenciones o de los miedos que nos acercan de manera sorprendente y no forzada a la mentalidad del hombre del medioevo.

${ }^{2}$ El discurso transmitido por los medios de comunicación de masas es un discurso anónimo, un discurso que no mantiene nadie en particular y que influye en todo el mundo. Como señala Sébastien Darsy (2005), la literatura medieval, como discurso anónimo es expresión de una clase social y de sus ideales e intereses.
} 
Como la literatura de la Edad Media, la publicidad actual presenta una alta redundancia. Su estructura formal básica es la repetición y el estilo formulario. Y su finalidad es la misma: permanecer en la memoria, convertir las repeticiones en afirmaciones categóricas, imponer un modo de vida.

Como la literatura medieval, la publicidad quiere ser útil, pragmática; es preceptiva (ordena), pero juega a persuadir. Se apoya en los mismos tópicos: la credibilidad del emisor, para ofrecer una apariencia de verdad o de realidad. El enunciador del texto medieval se apoya en la tradición, en la autoridad, y dice haber visto o haber oído contar lo que relata (lugar común imprescindible para abordar la narración), como el publicista se apoya en la ciencia o en la experiencia o en las convenciones culturales para presentarse como una voz creíble que se impone necesariamente. Literatura y publicidad acuden a las isotopías producidas por el propio sistema. Son intertextuales porque ésta es una prueba más de su credibilidad.

Como hay que persuadir para convencer, es necesario entretener para no aburrir. Éste es otro tópico que literatura medieval y publicidad comparten. En ambas es frecuente el elogio de la brevedad. En la literatura medieval ésta es una cualidad que se le atribuye al buen narrador. La publicidad es breve porque busca el relieve y el énfasis; las fórmulas comerciales, sintéticas y sorprendentes son las nuevas sentencias, las moralejas de la sociedad de consumo. Todo se resuelve en economía y eficacia.

El grado cero de la literatura medieval y de la publicidad es el superlativo, la hipérbole es su figura. El epíteto épico en los Cantares de Gesta y en los romans del siglo XII, la adjetivación de la lírica cortés, nos conducen a un mundo donde cada personaje, cada caballero, cada dama, es el mejor entre los mejores, sin que podamos oponer resistencia a esta paradójica jerarquía en la que el primer lugar es reiteradamente ocupado por múltiples personajes y objetos. Los anuncios siempre mostrarán lo mejor entre lo mejor, lo más, lo superior, el grado superlativo que no admite contradicción ni réplica.

Como la literatura medieval, la publicidad es pragmática, y para serlo se hace pedagógica. El intervencionismo explicativo es constante. Cuando la finalidad externa está clara, el anuncio debe ser revelador, ofrecer su comentario o simplemente hacerlo innecesario. El enunciador medieval crea alegorías o personajes que desde dentro de la ficción descifran los significados. Otra buena manera de hacerlo consiste en remitirlo todo al hombre. Se trata de materializar, de hacer los significados concretos a escala humana. Las imágenes antropomórficas y el animismo en general abundan en la literatura medieval. Disney y la publicidad contemporánea no han hecho más que recuperarlas. 
Para mantener los privilegios económicos (seguir vendiendo) o para mantener los privilegios de clase (de la nobleza, de los caballeros) es necesario que los demás los acepten (o que compren). La propaganda no vende sólo los objetos, ni los privilegios. La propaganda vende la idea de que éstos deben seguir en manos de quienes los disfrutan (en la Edad Media) o la posibilidad de alcanzarlos a cambio de dinero o de trabajo (publicidad actual). Por esta posibilidad el pueblo, los posibles consumidores, debe sentirse contento y agradecido. Pero esta posibilidad sólo se puede ofrecer en el marco de la ficción, como «narraciones», pues se trata de construcciones imaginarias, idílicas, optimistas, ya que lo que se pretende no es convencer racionalmente, con argumento y lógica, sino que se busca una adhesión acrítica y emocional. Por esto los caminos de la publicidad nos recuerdan los de la literatura medieval.

La publicidad, como la literatura medieval, es ante todo voz, música e imagen. Su iconografía, animista, colorida y concreta, recuerda la de las miniaturas y la de las catedrales, levantando ahora un templo al consumo material. Sus motivos, sus realizaciones, ya se reciclan y se ofrecen en collages como sinónimos de arte. La publicidad comienza a ser antigua y a gozar de prestigio (limpiándose de culpa). La literatura medieval se justificaba siempre diciéndose útil. La publicidad se redime transformándose en arte.

Existen muchos estudios sobre la publicidad que la relacionan con el discurso retórico. En estos trabajos se insiste en el empleo que hace la publicidad de las figuras del lenguaje. La relación de la publicidad con las vanguardias literarias y artísticas y con el uso creativo del lenguaje es un terreno de análisis que no se ha agotado. Pero mi propósito en este caso es otro; parto de la observación de dos momentos muy distantes, pero similares en muchos aspectos.

La publicidad aprovecha las posibilidades que encuentra en la retórica, juega con la lengua, es creativa, provoca extrañamientos, sorpresas, emociones. ¿Qué hace con los temas, con los contenidos? ¿aprovecha también los motivos, las estructuras culturales, sociales...?

La publicidad apela a mecanismos profundos, a convenciones bien establecidas, a los mitos, a los ritos. ¿Será también capaz en este caso de jugar con los modelos, de provocar extrañamientos, de establecer nuevos paradigmas? ${ }^{3}$ ¿podrá remover, cuestionar, afirmar o modificar el orden social?

3 «Un buen mensaje publicitario logra algo más que la mera promoción del consumo de un producto, consigue integrarse en ese depósito de la conciencia social donde se sedimentan los rasgos de la cul- 
El ritual del don es un paradigma, un ejemplo de estructura mental y retórica que es repetida, comprendida y aceptada en la Edad Media. El don se integra en el topos de la «afirmación del ideal del feudalismo» y del ideal católico de «la caridad». Forma parte de la propaganda política y religiosa que propone un mundo ideal donde todo es gracia, don, beneficio. Un mundo donde cada uno está en su lugar y no existe el interés ni la usura. Un mundo $\sin$ avaricia y $\sin$ pecado ${ }^{4}$. Este paradigma, de alguna manera, sigue funcionando en la publicidad actual. Una cantidad bastante considerable de anuncios publicitarios actuales se articulan sobre una «gramática de la amistad», calco creativo de la «gramática de la caridad» que definía la mentalidad medieval para la que todo era gracia, don, y eco, aún reconocible, del simbolismo del don en las sociedades primitivas.

Éste es el punto en el que centraré mi análisis, considerando principalmente dos variantes muy productivas en las narraciones medievales: el don anunciado y el don obligado (don contraignant), y la presencia de estas mismas estructuras retóricas en la publicidad de nuestra época, su pertinencia psicológica, su adecuación social y su función comercial.

Si los dones tienen un carácter económico, son sobre todo hechos sociales completos. La publicidad utiliza y juega con el carácter social, con la fuerza psicológica del don y sus significados no económicos, buscando otros efectos-resultados que sí son económicos, comerciales. Se busca una ganancia, pero se propone que la compra se efectúe con el significado del «don» para el comprador (así propone la publicidad que éste entienda su acto de compra), y con el significado o resultado meramente económico (de ganancia material) para el vendedor del producto. La expresión de este doble juego en la publicidad se articula en un retórica de la metonimia si observamos desde el lado del vendedor, y en una retórica de la metáfora si somos el comprador o posible comprador de un producto, de un bien de consumo.

Siempre han existido momentos y rituales establecidos para el intercambio de regalos. Se trata de una fórmula que contribuye a la estructuración de

tura de masas que la publicidad genera y fomenta. Influye en la configuración del código de valores sociales por el que se rigen las ideologías y las mitologías de nuestro tiempo» (A. López Eire, 1998).

${ }^{4}$ "Au point de départ il y a la théologie (...) Le droit n'est pas premier pour l'ordre social. Avant lui, il y a la charité, l'amitié, c'est-à-dire la «bienveillance mutuelle « et la justice (...) Ces principes, ces vertus dominent l'échange et permettent de le juger (...) On y retrouve les vertus de la relation féodale. Religión, piété, innocence, amitié, révérence, concorde, miséricorde. C'est là que se situe le «bénefice», qui est bienfait et procède de la «liberté féodale». La «charité» precède la justice. Le fief est merci et grâce. Ces concepts médiévaux ne sont pas évanouis aux Temps modernes» (Préface de J. Le Goff, Bartolomé Clavero, 1996). 
las sociedades, más aún, es quizás un elemento fundamental de socialización. Las fiestas y ceremonias son pretextos explotados por la publicidad. Son momentos propicios para los regalos, para establecer o consolidar lazos personales. Se les atribuye una cierta función mágica, suponen el retorno periódico de vastas operaciones de intercambio y de las campañas publicitarias asociadas.

Claude Lévi-Strauss (1981) habla de la importancia y del significado simbólico del don en las sociedades primitivas. Es particularmente esclarecedor en este sentido el capítulo V de Les Structures élémentaires de la parenté, titulado «Le Principe de réciprocité», y algunos momentos del capítulo VII, «L'Illusion archaïque».

Un don puede servir para compensar o «devolver» otro don, otro regalo, otro favor, y volver a un equilibrio que el primer don había puesto en peligro. El regalo servirá para volver a una situación de igualdad proporcional siempre comprometida. En la relación del don siempre hay alguien que queda en estado de inferioridad: el que recibe, que debe dar a su vez, por lo menos en la misma medida en que el otro, si quiere recuperar su posición perdida o amenazada. Su posición social, su poder frente al otro depende de la calidad y cantidad de su don (y de la intención), de sus regalos.

Este don no sólo sirve para restablecer una posición perdida, no es sólo una manera convencional de restituir los favores, de corresponder a los dones del otro. El don puede convertirse en un instrumento de acción social en manos del más poderoso o del más rico, o del más fuerte. Con el regalo uno puede señalar su posición social, poner de manifiesto un cambio de estatus, establecer y hacer reconocer su prestigio.

En todas estas estrategias, el valor material, objetivo, del regalo, se desdibuja frente a los significados simbólicos añadidos. El regalo funciona como un medio de comunicación, sintético, metafórico. El regalo es rito, puente en la relación interpersonal siempre difícil, a menudo conflictiva. El don sustituye a la batalla. Frecuentemente, el intercambio de dones es la réplica civilizada de intercambio de golpes o amenazas. Expresión concreta y disimulada de la rivalidad, pero expresión permitida, aceptada, e incluso sobrevalorada por la sociedad. Superar al otro sigue siendo la última razón, aunque camuflada, bien conocida y explotada por el lenguaje publicitario.

Además, el regalo se beneficia también de una especie de función mágica. Se da una respuesta a la rivalidad, se finge que la hostilidad se convierte en alianza (se compra al contrario, al enemigo, al otro) y se apacigua la 
angustia. Hacer un regalo produce satisfacción. Con el regalo se compra la tranquilidad, se establece la tregua. Los publicitarios, atentos a la psicología del comprador, saben que una gran mayoría de los consumidores preferimos tener un cierto protagonismo. Proponer comprar para regalar nos convierte en caballeros del consumo, nos hace escalar puestos en la jerarquía social, pues compraremos para practicar la largesse; la acción depende de nosotros, somos libres. Nos sentimos interpelados, aludidos, pero dueños del proceso, sin percatarnos de que la estrategia publicitaria está jugando precisamente con esta percepción sesgada de la realidad y de que la está poniendo a su servicio.

Los Cantares de gesta medievales son un buen ejemplo, depurado, de la práctica del don con los significados que acabo de señalar. Los Cantares, como publicidad, primero oral, de un modo de vida y de una ideología: la vida del guerrero, del caballero y el espíritu de la cruzada, se llenaron de fórmulas henchidas de significados simbólicos. La generosidad, largesse, definió la característica principal del caballero, su valía y su importancia, distinguiéndolo del hombre del pueblo, de los villanos y mercaderes, perdidos por su espíritu comercial y su avaricia. Da el que tiene, el que puede, al que le sobra. El caballero ha sido elegido para cumplir una honrosa misión, el caballero lo vale. El caballero da y así hace gala de su valor, de su poder y de su fuerza; demuestra que merece la posición que ocupa en la sociedad y la defiende de cualquier posible crítica. La práctica de la largesse calla las bocas y a él le otorga un nombre, y el nombre, un prestigio 5 .

Dar significa que uno es tan poderoso que puede permitirse no ser egoísta. Los héroes de los Cantares son larges, liberales. Así puede explicarse también el intercambio de regalos entre enemigos.

En La Chanson de Roland se enfrentan dos grandes de la tierra. El gran señor feudal, el emperador Carlomagno, cabeza de la cristiandad, y su paralelo, el jefe supremo de los paganos, y al servicio de éste, el rey Marsilio. Éste sabe que Carlomagno se dispone a atacarlos y él no cuenta con el ejercito apropiado para hacerle frente: qué hacer; pide consejo a sus vasallos.

La solución que le propone el más sabio de sus hombres reproduce el paradigma del don y su ritual: el regalo servirá para apaciguar al contrario, para

${ }^{5}$ La repetición de las fórmulas las convierte en máximas. La repetición crea la convención. Con ellas se puntúa el relato y se estructura con un fondo ideológico (doctrinal). Son el punto fuerte de la propaganda de los «dogmas» del feudalismo. 
romper o confundir su hostilidad. El regalo como respuesta a la angustia del donador y como una manera de «obligar», de doblegar al contrario:

Mandez Carlum, a l'orguillus e al fier,

Fedeilz servises e mult granz amistez.

Vos li durrez urs e leons e chens,

Set cenz camelz e mil hosturs muers,

D'or e d' argent .IIII. C. Muls cargez

Cinquante carre qu' en ferat carïer

Ben en purrat luer ses soldeiers.

En ceste terre ad asez osteiet ${ }^{6}$.

Se trata de darle, y de darle tanto para que se sienta conforme y satisfecho y bien pagado. Darle para que deje de combatir, de pretender más conquistas. Darle también para que crea que los que le dan son poderosos, que no será tan fácil vencerles, que tal vez la batalla no merezca la pena ${ }^{7}$.

Estilísticamente el don se convierte en una enumeración; metonimia del producto: osos y leones y perros, camellos y azores y oro y plata. Pero cada parte del don es algo costoso, algo difícil de conseguir, representa un lujo. No se le ofrecerá a Carlomagno algo corriente, nada que sirva para la satisfacción de necesidades cotidianas o vulgares; se le ofrecerá aquello que para un hombre de su condición, que lo tiene todo, pueda ser, sin embargo, objeto de deseo $^{8}$. Y se le ofrecerá en grado superlativo (las cifras tienen aquí una clara función intensificadora. La exageración que comportan contribuye a acercar la metonimia del don a la categoría de la metáfora, de símbolo del deseo). Así, el don se convierte en una relación comercial contaminada por lo simbólico, en la que se camufla el chantaje emocional. Si le ofrecen lo que desea, y en grandes cantidades, si recibir algo de otro significa que ese otro nos aprecia, si con el regalo se nos muestra que somos dignos de ese aprecio, ¿cómo seguir mostrándole enemistad? El regalo ha sido la fórmula, el lenguaje que ha servido de publicidad a todos esos significados. ¿Se tratará de

\footnotetext{
${ }^{6}$ «Enviad un regalo al orgulloso y altivo Carlos, ofreciéndole servicios y gran amistad. Le daréis osos y leones y perros, setecientos camellos y mil azores mudados, cuatrocientos mulos cargados de oro y plata y cincuenta carros para acarrearlo todo. Así podrá pagar a sus soldados. Ya ha batallado demasiado en nuestra tierra».

7 El don para «surpasser un rival en munificence, l'ecrasser, si possible sous la perspective d'obligations en retour auxquelles on espère qu'il ne pourra satisfaire, de manière à lui arracher privilèges, titres, autorité...» (Lévi-Strauss, 1981).

8 «il existe certains types d'objets spécialement appropriés (le plus souvent par leur caractère non immédiatement utilitaire) à faire des cadeaux» (Lévi-Strauss, 1981).
} 
una publicidad efectiva? Esto lo dirán los resultados, la acción que desencadenen. De alguna manera Carlomagno compra, o eso parece. Antes de que el don tenga lugar es repetidamente anunciado, como si al convencimiento se quisiera llegar también mediante la insistencia. Publicidad recurrente cuya finalidad no es otra que doblegar al «comprador». La laisse IX repite el contenido del don, ahora en estilo directo; Blancadrin, el mensajero, habla al rey:

\author{
Iço vus mandet reis Marsilies, li brees [...] \\ De sum aveirvos voelt asez duner, \\ Urs e leuns e veltres enchaignez, \\ Set cenz cameilz e mil hosturs muez \\ D'or e d'argent HI cenz muls trussez \\ Cinquante care que carier en ferez; \\ Tant $i$ avrat de besanz esmerez \\ Dunt bien purrez vos soldeiers luer 9 .
}

$\mathrm{Al}$ efecto acumulativo de la repetición se añade el del estilo de la laisse, acumulativo también, pues la metonimia se resuelve en enumeración, en un efecto de lista al que contribuye también el polisíndeton.

Más adelante, en la laisse número XIII, de nuevo el don es detallado. Esta vez es Carlomagno quien lo transmite como noticia y motivo de reflexión a sus hombres, solicitando su consejo:
Seignurs barons, dit li emperere Carles,
Li reis Marsile m'ad trasmis ses messages
De sun aveir me voelt duner grant masse,
Urs e leuns e veltres caeignables,
Set cenz cameilz e mil hosturs muables
Quatre cenz mulz cargues del or d'Arabe, Avoec iço plus de cinquante care ${ }^{10}$.

Con muy ligeras variaciones en la adjetivación, Carles reproduce las palabras del mensajero, como una fórmula (eslogan) bien aprendida. Pero, ¿la

\footnotetext{
9 «Esto quiere deciros el rey Marsilio, el afamado / De sus bienes quiere daros gran parte / Osos y leones y galgos enlazados / Setecientos camellos y mil azores mudados / Cuatrocientos mulos cargados de oro y plata / Cincuenta carros para acarrearlo todo / Pues habrá una grandísima cantidad de besantes dorados / Con ello bien podréis pagar a vuestros soldados».

10 «Señores barones, dice el emperador Carlos / El rey Marsilio me ha enviado mensajeros / De lo que posee quiere darme una gran parte / Osos y leones y lebreles enlazados, / Setecientos camellos y mil azores mudados / Cuatrocientos mulos cargados con oro de Arabia / y además cincuenta carros».
} 
repetición hará su efecto? El regalo comporta una condición, exige una contraprestación, un precio proporcional a su valor - las cifras son sorprendentes, superlativas, hiperbólicas-, un valor de cambio enorme: la contrapartida del regalo exige que Carlomagno se vuelva a Francia y que deje de combatir contra ellos. Hay que insistir mucho en la importancia del regalo, anunciarlo, repetirlo, adornarlo, para que la simple metonimia de su presentación y de su descripción empiece a funcionar como una metáfora: hay que jugar con una valoración simbólica del producto, del objeto del don, para poder contar con una mínima posibilidad de éxito.

La publicidad actual también está inmersa en el ámbito de la reciprocidad; cuenta con la aceptación de este paradigma para utilizar sus esquemas. Como señala Lévi-Strauss (1981: 65):

Tout se passe dans notre société, comme si certains biens, d'une valeur de consommation non essentielle, mais auxquels nous attachons un grand prix psychologique, esthétique ou sensuel, tels les fleurs, les bonbons, et les «articles de luxe», étaient considérés comme devant convenablement s'adquerir sous la forme de dons réciproques, plutôt que sous celle de l' achat et de la consommation individuels.

Pero el éxito no será el resultado de la empresa en La Chanson de Roland. El regalo de Marsilio se presentaba como simbólicamente equiparable a la tierra de España, la que Marsilio pretende obtener en contrapartida, como contra-don (feudo) del emperador Carlomagno.

Dones simbólicos, pero que se negocian como mercancías. Carlomagno se hace aconsejar por sus barones y no ofrecerá a Marsilio más que la mitad de la tierra que le pide (la estrategia se envilece en regateo o marchandage), y será eso o la guerra, eso o la muerte. Ganelón será el encargado de llevar este nuevo mensaje:

Si li ad dit: «A tort vos curuciez,

Quar ço vos mandet Carlis, ki France tient,

Que recevez la lei de chrestiens;

Demi Espaigne vus durat il en fiet

Si ceste acorde ne volez otrier

En Sarraguce vus vendrat aseger;

Par poëstet serez pris e lïez, 
Vus n'i aurez palefreid ni destrier

Ne mul ne mule que puissez chevalcher,

Getet serez sur un malvais sumer

Par jugement iloec perdrez le chef ${ }^{11}$.

Hasta el momento, ningún regalo ha tenido lugar, ninguno se ha hecho efectivo. La batalla del don es una guerra dialéctica, una confrontación de palabras. Anuncios y contra anuncios. Vemos ahora la respuesta a todas las riquezas que ofrecía el rey Marsilio (a su alarde de poder y a su compra de indulgencia). La propuesta de Carlomagno cobra fuerza y relieve sorprendente porque responde, oponiéndose (retórica de la antítesis) al exotismo, al lujo y al significado de nobleza de los regalos de Marsilio. Marsilio sólo será caballero si se somete al poder de Carlomagno, será caballero, pero vasallo. Carlomagno le ofrece media España como feudo; si Marsilio acepta y además abraza la fe de los cristianos, conservará, bien menguados, sus privilegios. Si no acepta, sus mulos cargados de oro y plata, sus riquezas, los animales exóticos, los perros de caza y las magníficas aves de cetrería (todos símbolos de un modo de vida aristocrático y libre) se trocarán en servidumbres y prisiones; el caballo de guerra en bestia de carga (reservada como cabalgadura sólo a los más miserables), todo su poder en deshonor y muerte (será ajusticiado como un proscrito) ${ }^{12}$. Si la respuesta de Carlomagno prueba que el artificio del don no ha funcionado (otra manera más de señalar que del lado de los cristianos se encuentran también los consejeros más sabios), prueba también, sin embargo, que se ha jugado con su significado simbólico y que éste ha sido entendido y bien interpretado por las dos partes.

La estructura maniquea de La Chanson de Roland reproduce la hostilidad fundamental entre los seres, su bipartición: yo y «los otros», o nosotros, lo nuestro, nuestro mundo y los otros, los enemigos. Es este principio dualista de hostilidad lo que confiere a un objeto su valor. Nos importa cuál es el valor de los objetos para los otros, y nos interesa lo que tiene el otro, deseamos

11 «Así le ha dicho: No tenéis razón al enfadaros / Pues esto os ofrece Carlos, el emperador de Francia / Que adoptéis la ley de los cristianos / Os dará media España como feudo /.../ Si no queréis aceptar este acuerdo / Vendrá a sitiaros en Zaragoza / Por orden suya seréis atado y preso /.../ No tendréis palafrén ni caballo de batalla / Ni mulo ni mula que podáis cabalgar / seréis llevado sobre bestia de carga / Y después de un juicio se os cortará la cabeza».

${ }^{12}$ Se aprecia ahora con claridad la presencia del principio dualista (otra modalidad del principio de reciprocidad). El don podría haber contribuido a asegurar el paso de la hostilidad a la alianza, pues como señala Lévi-Strauss (1981) «les échanges sont des guerres pacifiquement résolues, les guerres sont l'issue de transations malheureuses». 
lo que el otro posee. Marsilio ofrece a Carlomagno darle «gran parte de lo que tiene». Ofrece mucho para no quedarse sin nada.

Algunos argumentos de la publicidad contemporánea utilizan exactamente el mismo esquema. Ponen a punto anécdotas, relatos, que contraponen dos posibilidades (juegan con esquemas binarios en la estructura y en el estilo), ofreciendo comparaciones, antítesis, en las que muchas veces se incluye el humor. Hacer reír al público que deberá, supuestamente, elegir por sí mismo entre las dos posibilidades, dirige y asegura en cierto modo la respuesta. Imaginar a Marsilio sobre una bestia de carga debía forzosamente inclinar a los oyentes medievales hacia la opción opuesta: ponerse incondicionalmente de parte de Carlomagno y de los cristianos.

En la campaña publicitaria 2004, cuando Peugeot lanzó uno de sus últimos modelos como «El mejor coche del año», las imágenes ofrecían para facilitar el contraste «otros» modelos, sin comentarios. Las características que estas imágenes resaltaban eran todas negativas y aparecían cargadas de matices irónicos: se trataba de coches excesivamente simples, reducidos a sus elementos imprescindibles, de colores totalmente fuera de la moda (del paradigma imperante), de diseño claramente anticuado (siempre según las convenciones del momento), y la anécdota, sin palabras, mostraba a sus propietarios visiblemente insatisfechos, fastidiados, diferentes, fuera de lugar o de onda, carentes de posición social y evidentemente sin ningún prestigio..., como estaría Marsilio, caballero sin caballo, arrojado sobre una bestia de carga. Y dando cuerpo a la otra cara de la moneda, en perfecta y lograda antítesis, único frente a la pluralidad informe de los «otros», aparecía, brillante, magnífico, poderoso, el que había sido considerado «mejor coche del año», superlativo, y a su lado, su flamante y orgulloso propietario.

Nosotros y «los otros». La valoración y la risa (o el escarnio). Nosotros y lo que nos hace diferentes, lo que nos distingue, lo que nos individualiza y lo que nos integra en una clase, en un orden. Pero curiosamente, para sentirnos únicos se nos dice que tenemos que adquirir lo que tienen otros. Y esos «otros» de los que deberíamos desear formar parte, se nos presentan como modelos. Por mucho que pudiéramos comprar o adquirir, los modelos son inalcanzables, porque su carrera vertiginosa traspasó hace tiempo las fronteras de la realidad y se hizo simbólica en un universo de ficción, de palabras e imágenes virtuales. Nada es lo que parece. Nos ofrecen símbolos, la perfección, mundos utópicos, pero compramos productos. Los vendedores se enriquecen y los consumidores nunca están saciados. 
Esta característica de las ficciones medievales y de las ficciones publicitarias modernas constituye el blanco de muchas críticas ${ }^{13}$.

Se critica el consumismo del mismo modo que antes se atacaba la avaricia como el mayor de los vicios. El paradigma del don y de la gracia reglamentaba una economía que pretendía escapar así al pecado de la usura ${ }^{14}$. La contra-prestación o el don era siempre gratuito, gratis. Así funcionaba el beneficium feudal ${ }^{15}$. Ante la disyuntiva amistad o precio, se pronuncia una teología de la amistad. La intención es el criterio que los delimita. La gratuidad hace lícitos los intercambios, los negocios. El don es libre. Se trata de una obligación no obligatoria. Contiene el agradecimiento y supone la amistad. Una obligación natural aceptada por convención religiosa y social que favorece una «economía de la gratitud», no sometida a leyes. La amistad prima sobre el derecho y la justicia institucionalizada.

Esta mentalidad de la gracia obliga a los poderosos a ser generosos, graciosos, liberales ${ }^{16}$. Una serie de ideas y preceptos religiosos sobre la caridad funcionan como una regla general para las relaciones humanas. Desde Dios hasta la banca, todo funciona como una sociedad de patronos y clientes. Los santos son patronos protectores, ofrecen protección como contrapartida de ofrendas y oraciones. El cliente, fiel, espera contrapartidas de su homenaje a Dios.

El paradigma medieval del don es deudor de esta teología, de toda esta enseñanza que una literatura «útil» no deja de difundir. Pero la literatura me-

${ }^{13}$ Michael Löwy (director de investigación del CNRS y miembro de la Asociación de resistencia contra la agresión publicitaria) considera que estamos acosados por las propuestas de vida imposible que muestra y «ofrece» la publicidad. Sin embargo no todo son críticas negativas. La publicidad, como los relatos, es también una fuente de información que crea lazos, que nos socializa, y su estética, su estilo, su colorido, contribuyen a la alegría o a la evasión como el relato de una aventura. En este sentido, el filósofo Robert Redeker propone el elogio de la publicidad, aunque, muy posiblemente, sólo esté teniendo en cuenta un tipo de publicidad idílica que efectivamente puede funcionar como respuesta (engañosa) al derecho a soñar.

${ }^{14}$ Según J. T. Noonan «a vu, au moins pour une époque donnée qu’à une conception religieuse correspondait une incarnation sociale. Concernant le Moyen Âge, un motif comme celui de la grâce appliqué à l'économie peut faire l'objet de ce type d'analyse» (Clavero, 1996: 17).

15 «C'est l'antidora, mot grec (...) auquel correspond le «beneficium» latin. C'est la contre-prestation, oserais-je dire le « contre-don» (...) Cette contreprestation demeure toujours gracieuse. «Gratis» est depuis la Bible le mot d'ordre du système. Tel est le paradigme général porteur de sens économique» (J. le Goff: Préface, B. Clavero, 1996).

${ }^{16}$ Esta pedagogía se extiende más allá de la Edad Media. En el Doctrinal de príncipes se enumeran las condiciones que tiene que cumplir el hombre liberal. La primera es que dé sin demora y dé de buen grado. En Flor de Virtudes e de Costumbres (segunda mitad del siglo XV), la libertad se describe como una disposición gratuita flanqueada por dos vicios: el despilfarro y la avaricia. La avaricia se denomina también «pobreza de corazón» y es la raíz de todos los males. 
dieval también conserva y explota el don con un significado antropológico mucho más primitivo y tal vez más directamente relacionado con los mecanismos de la psicología humana, sin mediaciones hacia la trascendencia. Hoy ambos paradigmas siguen activos; se combinan y se modifican. No es cierto (cada anuncio es una prueba de lo contrario) que hoy la dimensión de la intención haya dejado de ser importante ${ }^{17}$.

Los setecientos camellos, los cuatrocientos mulos cargados de oro, los mil azores del Cantar también eran virtuales. Y eran virtuales los veinte mil hombres que reunía Carlomagno y preparaba para la batalla. Las exageraciones y las excepciones hablan del deseo. Las ficciones de la Edad Media, aunque fingieran adoptar el paradigma de la crónica, se ofrecían también como la realización de sueños, como la propaganda de un modo de vida que merecía conservarse y respetarse, aunque muy pocos fueran los elegidos llamados a vivirlo.

La publicidad, como los Cantares y los romans, contribuye a conformar la mentalidad colectiva. De algún modo homogeneiza a los receptores. Los anuncios son escaparates de la sociedad donde se exhiben los estereotipos dominantes; son reflejo de la sociedad y tienen un poder y una eficacia reales. Contribuyen a organizar el espacio social de acuerdo con los valores de quienes imponen y delimitan la estrategia comunicativa, los anunciantes, o los mecenas.

Como un anunciante, Marie de Champagne o Philippe de Flandre ${ }^{18}$ son quienes pagan el soporte donde se difunden sus mensajes. Esta circunstancia les otorga un gran protagonismo, reconocido explícitamente por quien da cuerpo y forma al anuncio, al relato.

La literatura medieval, como la publicidad, funciona como un sistema de comunicación pagada, intencional, interesada, que sirve siempre a causas comerciales, sociales o políticas concretas. Si se trata de mostrar la caballería o la cortesía como modelos, o de justificar su existencia en la sociedad, hay que exhibirlas dotándolas de brillantez.

Al hombre medieval se le proponen modelos pero se le recomienda que permanezca en su lugar (en el «orden» 0 «estado» que Dios determinó para

17 Según J.T. Nooan, «la dimension de l'intention dans la réception des faveurs est plus importante que ne le laisse soupçonner notre époque commerciale pour laquelle le cadeau a cessé de constituer une source régulière de bénéfice; au Moyen Âge la contrepartie des prêts s'effectuait expressément comme un don; c'est à tout le moins ce que déclaraient formellement les rois et les États» (B. Clavero, 1996).

${ }_{18}$ En el exordio de los romans de Chrétien de Troyes: Le Conte du Graal y Le Chevalier à la charrette. 
él desde un principio). Podría pensarse en la ambigüedad o en la inconsecuencia de tal práctica, pero, en primer lugar, son las clases altas, las élites en el poder, las que anuncian, proponen o «venden» su modo de vida, no para que los otros lo alcancen o lo «compren», sino para que lo comprendan, lo admiren, lo acepten y lo respeten. La élite se anuncia para comprar la continuidad de sus privilegios. Los modelos sólo se ofrecen a la admiración alejada y sumisa del pueblo. Si el carácter pragmático y pedagógico de la literatura medieval es evidente ${ }^{19}$, también lo es para nosotros la contradicción que encierra, y la imposibilidad de adquirir o alcanzar, para la gran mayoría, los «bienes» que anuncia.

Si nos fijamos en las tres partes fundamentales de la retórica: la inventio, la dispositio y la elocutio, considerando que la inventio se ocupa de «hallar qué decir», en la publicidad el paradigma del don es uno de los más repeti$\mathrm{dos}^{20}$. Para articularlo, la dispositio funciona en el anuncio como en una pequeña ficción. Estructura el material siguiendo el mismo esquema: un exordio, una parte central narrativa (o argumentación) y un epílogo que resume el «tema» y se dirige de nuevo al destinatario, cerrando el mensaje con la firma o la marca del producto (L. Sánchez Corral, 1991). Y la elocutio deberá ocuparse de mantener la transparencia codificada del mensaje publicitario.

También he señalado antes la posibilidad de una aproximación al ritual del don en la publicidad, entendido como una retórica de la metonimia y de la metáfora. Quisiera ahora observar este proceso con más detalle.

Cuando se presenta un producto al público consumidor ocurre algo semejante a lo que sucede en la presentación o puesta a punto de un personaje. El bien de consumo, el objeto o el don, adquiere una posición central y como tal participa de una historia, de una pequeña anécdota. Es parte de una narración. Desde este punto de vista, los estudios de Greimas (1987) van a sernos de gran utilidad.

Una manera frecuente de presentarnos los objetos ${ }^{21}$ es dotándolos de un nombre propio, sonoro y sugerente que los identifique, detallando a conti-

$19 \mathrm{Y}$ se pone de relieve especialmente en las obras que utilizan el cuadro del «debate» como estrategia de una dualidad en la que la elección está claramente dirigida (debates entre el bien y el mal, el vicio y el pecado, Dios y el diablo...).

${ }_{20}$ Se repite mucho más el paradigma del don positivo que el del don negativo. Resulta más rentable, apoyándose en la psicología, ofrecer la posibilidad del don, del premio, de la gracia o del regalo, que amenazar con la falta o la privación de éste.

${ }^{21}$ No todos los objetos de consumo se presentan como dones, aunque es muy frecuente, excesivamente frecuente para no preguntarse por qué, que la publicidad adopte esta fórmula. Se nos presentan bie- 
nuación las características que los conforman; todo aquello que lo hace ser como es, aquello que lo diferencia y lo individualiza frente a «los otros» (objetos de la competencia) y que lo hace deseable. Todos los productos que se proponen al consumo deben poder convertirse en «objetos del deseo»; en esta metamorfosis se pone en juego la fuerza y la pertinencia de la publicidad.

El conjunto de detalles y características se presenta como un lexema, como un conjunto de semas ligados entre sí y no como una simple colección sémica. Se trata de una verdadera metonimia donde cada elemento, cada parte remite al todo, habla del todo ${ }^{22}$; donde cada elemento mantiene con los demás relaciones jerárquicas y sintácticas en el plano del discurso. Estas relaciones que existen entre los semas en el interior del lexema, pueden existir entre los lexemas en el interior de las unidades del discurso más amplias. La baza de la publicidad está en su posibilidad de elección. La libertad total supone un peligro: puede caerse en el absurdo incomprensible o provocar unos resultados que no eran los deseados, pero la libertad asegura también la explotación de la originalidad con fines publicitarios. Como la originalidad es un valor en la cultura actual, una estética original o la explotación del humor puede ser una manera de llegar a ciertas franjas de público. El discurso publicitario puede elegir las isotopías adecuadas y las metonimias y metáforas significativas. Cuenta con el universo semántico almacenado, conoce el campo cultural. Pero, ¿cómo establece la publicidad los semas comunes? ¿cómo los elige? ¿de acuerdo con qué criterios?

Cuando se investigan dominios insólitos del lenguaje, como por ejemplo simbolismos mitológicos, poéticos, oníricos..., se da una tendencia muy clara a considerar el lexematismo antropomórfico, es decir, el sentido relativo al hombre, como el primero. ¿No podría ser también esta tendencia la que guiara el acercamiento al lenguaje y al simbolismo de la publicidad?

Es una constante que los objetos sean presentados mediante detalles y características que contribuyen a humanizarlos. Muchas veces se les dota de

nes señalándonos la posibilidad de ofrecerlos como regalo a un tercero; pero incluso las compras que uno hace para sí mismo son «un regalo» que merecemos.

${ }^{22}$ La expresión metonímica se convierte frecuentemente en un verdadero ejercicio retórico de adjunción. El «tema» concentrado en la «marca» requiere la presentación de expansiones. Éstas se resuelven en enumeraciones acumulativas con matiz amplificador, intensivo, en construcciones de esquemas paralelísticos binarios. «La mera seriación de los éxitos de venta, de las cualidades simbólicas o de las características técnicas se presentan como razones suficientes para comprar el objeto promocionado, sin que sea necesario dar argumentaciones sólidas y bien tratadas» (L. Sánchez Corral, 1991: 113). 
movimiento propio y de palabra. Se les convierte en actantes, frecuentemente en héroes, del mini relato que los conforma. Un animismo alegre los llena y les da vida. Los recipientes de detergente desarrollan extremidades y órganos fonadores, se mueven con gracia y cantan al ritmo de la faena. El frasco del producto de limpieza genera un mayordomo pulcro y eficaz que regresa al receptáculo tras la tarea como el genio que vuelve a la lámpara. Los cereales del desayuno, las galletas, las verduras..., tienen brazos y piernas, cara, ojos, nariz y boca, escuchan y hablan, proponen y aconsejan, responden a los estímulos..., tienen alma, y pueden reír o llorar, exaltarse o deprimirse, adoptando una psicología humana elemental o complicada, a imagen y semejanza del público al que se alude, a imagen y semejanza del hombre.

Es muy importante proveerse y rodearse de los objetos adecuados (dones) porque éstos nos reflejan, o nos completan, o nos hacen.

En la literatura oral de la Edad Media no se procedía de otra manera. Como en los simbolismos mitológicos y oníricos, el universo en general está animado; cada parte, cada elemento tiene vida y remite al todo. Cada elemento significa; los osos y los leones y los azores mudados y los perros de caza, significan un modo de vida, la riqueza, el lujo y el poder de la élite social que quiere conservar sus privilegios. A mayor fuerza significativa más se acerca el objeto a la categoría humana. ¿Qué hay más importante para un caballero que su caballo? ¿qué será más importante que su espada, símbolo de su libertad, de su misión y de su fuerza? Las espadas de los héroes tienen nombre propio y una historia, grandes proezas que relatar; están consagradas y significan la presencia divina en la tierra, justifican la razón humana, y la guerra. Se le puede hablar a una espada. Cuando Rolando, a punto de morir, se dirige por tres veces a Durandarte (las célebres tres laisses paralelas) el monólogo no podía confundir al público de las plazas ${ }^{23}$. Rolando se lamenta de su suerte, pero como buen vendedor de caballería y virtudes épicas en su discurso está el poder para convencer a un auditorio de hombres simples y de

${ }^{23}$ «La razón que subyace para que se prefieran las imágenes antropomórficas hay que buscarla en la estructura profunda del discurso. Esta razón no es otra que la de recubrir el proceso de metamorfosis publicitaria que experimentan las mercancías desde la objetivación de la producción económica hasta la adquisición de su identidad como sujeto activo de la historia de seducción que nos relata. El contexto antropomórfico así conseguido contribuye a crear un clima de verosimilitud de la ficción que hace creíbles y familiares la prosopopeya y la apóstrofe. Mediante la primera figura, el objeto personificado llega a convertirse en voz narrativa y en enunciador del mensaje. Mediante la segunda figura, el actante destinador puede permitirse el diálogo con el objeto personificado» (Sánchez Corral, 1991: 166). 
guerreros, alabando, repetidamente, las virtudes y adornos de su espada. Sentimientos, virtudes y adornos humanos ${ }^{24}$ :

E! Durendal, bone si mare fustes!

Quant jo mei perd, de vos nen ai mais cure

E! Durendal, cum es bele e clere e blanche!

Cuntre soleil si luises e reflambes!

Mielz voeill murir qu' entre paiens remaigne.

E! Durendal, cum es bele e seintisme!

En l'oriet punt asez $i$ ad reliques

Il nen est dreiz que paiens te baillisent;

De chrestiens devez estre servie ${ }^{25}$.

La espada de Rolando (un don merecido y bien utilizado en múltiples batallas y conquistas) escucha las alabanzas que se le dirigirían a una dama de convencional y sorprendente belleza: bella, clara y blanca, brilla al sol como la cabellera rubia y luminosa. Y es santa y debe ser servida, como dama cortés, sólo por caballeros que lo valgan, por caballeros cristianos. El objeto hace al poseedor, le otorga las características y los atributos que le confieren valor. Sin el objeto (sin el don) no hay identidad, no somos nadie. Ésta es una cara del mensaje de la publicidad, una de las fórmulas, de las estructuras que pretenden convencernos de la necesidad del producto, de la exigencia y de la libertad del don.

A partir de la realidad, la publicidad propone ajustes. La realidad es anodina, monótona, aburrida, amarga..., a menudo vulgar. La publicidad, como los cuentos $^{26}$, propone lo excepcional, lo sorprendente, lo extraordinario.

24 Laisses 171,172 y 173.

25 « Ay, buena Durandarte, qué desgracia la tuya! / Cuando yo muera ya no podré ocuparme de ti /.............. / ¡Ay, Durandarte, qué bella eres, y qué luminosa y qué blanca! / ¡Contra el sol reluces y echas llamas! /........................./ Prefiero morir que verte entre los paganos. /...... /iAy Durandarte qué bella y santa eres! / Tu empuñadura de oro está llena de reliquias /............ / No es justo que caigas en manos de los paganos / Por cristianos debes de ser servida».

${ }^{26}$ Comparte también con los cuentos el carecer de coordenadas espacio-temporales precisas. Su espacio y su estado es utópico y eufórico, y por lo mismo sus aseveraciones se tornan contundentes, absolutas. 
La publicidad es exagerada, hiperbólica ${ }^{27}$. Y todo esto debe concentrarse en las estructuras adecuadas, en fórmulas sintéticas y poderosas que sea fácil memorizar y repetir. El estilo formulario de los Cantares de gesta o el epíteto épico, asocian el producto con su marca como lo hacen los eslóganes publicitarios; sintetizan el concepto que desean transmitir con palabras plenas y hacen que este concepto tenga carácter de identificación y que perdure en la memoria, que se repita y que influya, que mueva a la acción, a la «compra». El producto se asocia así con su marca, la marca significa todas las «bondades» del producto y su recurrencia permite su evocación en otros contextos. Por la marca es reconocido.

«Guillaume au cort nez» no es cualquiera, puede dejarse admirar en diferentes cantares (anuncios). La predicación que lo acompaña siempre lo particulariza y lo idealiza, lo convierte en un modelo y lo propone a la admiración. Es el gran caballero que luchó con el gigante Corsolt a las puertas de Roma y que lo derrotó. La deformidad de su nariz, la herida, contará siempre la importancia de su hazaña ${ }^{28}$.

El epíteto épico, como el eslogan, recoge la principal cualidad del producto, el atributo diferenciador o el beneficio específico que se le atribuye.

En cuantos anuncios se nos pregunta: ¿todavía no lo tienes? ¿qué haces que no lo consigues (compras)? ¿aún no se lo has regalado? ¿aún no te lo has regalado? y la fórmula nos interroga más profundamente, entre líneas, entre imágenes: ¿lo mereces? ¿lo merezco?

El orgulloso Rolando respondía afirmativamente, seguro de que merecía a Durandarte. La prueba es que la consiguió como un don, porque a él estaba destinada $^{29}$ y que la ha servido con honor en las batallas. Hoy, la publicidad de muchos productos nos interpela en el mismo sentido. Los productos no son santos, pero su adquisición puede redimirnos, ¿lo merecemos?

Señalarnos la necesidad de adquirir para regalar a otro está muy bien visto. Valores como la observación, el interés por los demás, el sentimiento de participación o la generosidad (nueva largesse) justifican con creces la

${ }^{27}$ El superlativo y la hipérbole son las figuras más repetidas en los Cantares de Gesta. Tan convencionales que Chrétien de Troyes puede permitirse en sus romans jugar con ellas.

${ }^{28}$ El carácter excepcional es aún más evidente por el juego de las oposiciones. En la Edad Media, cortar la nariz era un castigo reservado a los malhechores. Este signo, en el caso de Guillermo, tiene un simbolismo bien distinto.

${ }^{29}$ La Chanson d'Aspremont lo cuenta y justifica. Hoy también se recurre a la técnica de anuncios por episodios, con la explicación diferida, con la explotación narrativa y pragmática de la intriga. 
compra. La publicidad intenta convencernos de la necesidad del don. En el don al otro no hay culpa. Los anuncios pueden saltar fácilmente este escollo. No hay censura. La publicidad aprovecha este privilegio en campañas concretas que cuentan con la sanción favorable de la sociedad y de la cultura. El rito del don desborda con su exceso en las campañas navideñas. Regalar se presenta como una acción básica, esencial, primordial. Si no regalas no eres, no existes. No te ven. Otras campañas de menor importancia (Día del padre, Día de la madre, Día de los enamorados...) reproducen el mismo esquema, el mismo artificio, el paradigma del ritual del don. Y en muchos casos se nos precisa que no seamos tacaños, avaros (ese gran pecado medieval), que no regalemos cualquier cosa. En la campaña navideña 2005 una empresa anuncia: «Esta Navidad, regala de verdad» y una mano desprecia con un golpe los socorridos regalos: calcetines, corbatas, colonias, diminutos y tristes como canicas, y muestra los verdaderos regalos, productos de la empresa, de dimensiones y precios considerablemente superiores.

Pero se necesitan otras fórmulas para «justificar» el gasto, y hay muchos consumidores potenciales solitarios que pocas veces tienen que participar en el compromiso social del regalo. Se trata entonces, copiando el esquema, de adaptar el ritual del don a una estructura egoísta y no culpable, donde el destinador y el destinatario del don sean la misma persona ${ }^{30}$. Se trata de justificar los regalos a uno mismo, revalorizando el carácter singular y borrando la culpa. Curiosamente muchos productos se ofrecen como «tentaciones»: el enemigo, materializado, concreto, en el producto, intenta seducirnos. Un perfume puede llamarse «Diábolo» y presentarse con los rasgos a los que nos ha acostumbrado la iconografía religiosa tradicional. La presencia y la fuerza de la convención hacen posible su explotación irónica y su actual finalidad.

Rolando se considera merecedor de Durandarte; cada caballero aventurero se consideraba elegido, merecedor de su espada, de su caballo, de su dama, porque había superado ciertas prueba (tres concretamente). Hasta su nombre era un don merecido.

La publicidad copiando y degradando el modelo, nos señala como merecedores de los productos sin aventuras, sin trabas, sin pruebas, merecedores del regalo porque sí (porque el producto necesita compradores). Otorgando valor a lo superfluo, a lo gratuito, a lo innecesario, a lo que sólo tiene valor

${ }^{30}$ Como en los cuentos de la búsqueda cuyo «esquema egoísta» hace del sujeto el beneficiario de la «quête» y el merecedor y finalmente dueño del objeto; sea éste un caballo, un castillo, o una princesa... 
de cambio y no utilidad práctica, se nos incita: «Date el capricho», se nos justifica : «Porque tú lo vales», o de modo aún más directo, para que la identificación resulte más cómoda: «Porque yo lo valgo» (eslóganes de las campañas de L'Oreal 2004 y 2005). Son afirmaciones simples, que no encuadra ningún relato, que no se argumentan. Sólo aparecen las características excepcionales y superlativas del producto y la promesa de autoafirmación que se hará efectiva en el acto de la compra. La relación sujeto-objeto se simplifica. El camino, la distancia entre uno y otro, la quête, se resuelve sin aventuras. La única aventura es la compra.

A los significados de mercado, económicos, se añaden los significados sociales de la compra, y los significados psicológicos. Las categorías actanciales de Greimas podrían ser útiles para interpretar la relación comunicativa que se pone en marcha en el ritual del don y en toda relación publicitaria que la explote. Puede resumirse en el siguiente esquema:

SUJETO OBJETO (modulación del poder) DESTINADOR DESTINATARIO (modulación del saber)

Si el sujeto accede al objeto, si lo consigue, adquiere más poder, y como destinatario de la relación, adquiere también más saber, el que antes estaba sólo en poder del otro (destinador). Tras el hecho comunicativo, el destinador también sabe y se produce una reorganización de la relación, ahora se da una relación de equivalencia, se nivelan, momentáneamente, los saberes.

Este esquema que reflejaría el movimiento relacional y la interacción de cualquier acto comunicativo, en el discurso publicitario se duplica en espejo (como de algún modo lo hace también en todo discurso de ficción):

\section{ANUNCIO}

\section{DESTINADOR}

Adquiere poder

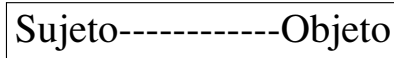

DESTINATARIO

Cree adquirir poder

(al adquirir el objeto)

El anuncio publicitario funciona como un microuniverso narrativo, como una mini ficción. El destinador puede definirse ahora como el vendedor del producto y el destinatario como el posible comprador al que hay que convencer de la necesidad o pertinencia de la compra. 
El esquema del anuncio reproduce en espejo el esquema de la comunicación. Dentro de esta estructura es muy frecuente que el sujeto represente al destinatario ofreciéndole la imagen de sí mismo que tendría una vez adquirido el producto (una proyección del deseo). Con el «anuncio» se trata de hacer ver o de hacer creer (espejo proyectivo) al destinatario que tendrá «poder», pero lo que se trata de provocar es la compra. Y la compra, a quien da realmente poder (fuera de la ficción del anuncio) es al destinador (vendedor del producto).

La estructura del mensaje impone una cierta visión del mundo. La relación entre sujeto y objeto (en el marco del anuncio) se convierte en manifestación semántica del deseo que puede combinar en distintos grados su forma práctica (características materiales del producto) o mítica (características simbólicas). La publicidad trata de conferir al objeto aquéllas características y cualidades que son positivamente valoradas por el destinatario, de dotarlo de los detalles y matices en acuerdo con el universo simbólico del sujeto.

En una cultura donde se valora la originalidad, donde prima la estética de lo nuevo, la importancia de la sorpresa predominará en la retórica publicitaria, poniendo a punto una dialéctica convención-sorpresa capaz de intrigar y de convencer al destinatario. Hay que señalar, sin embargo, que el abuso de esta retórica está conduciendo ya a su desgaste, lo que obligará a idear nuevas fórmulas comunicativas. A menudo la crítica de los modelos publicitarios al uso genera una nueva forma de publicidad, valorada incluso como fenómeno estético ${ }^{31}$.

La relación entre sujeto y objeto en el anuncio publicitario reproduce una relación de deseo y nos conduce a pensar de nuevo en una retórica volitiva. El «valor» de un objeto no está, en principio, definido ni establecido. Contribuyen a configurarlo las convenciones sociales y los propios sujetos. El «valor» del objeto puede dar respuesta a consideraciones de carácter práctico o mítico. En cualquier caso lo que se propone al sujeto es una «búsqueda» del objeto, (donde los parámetros de facilidad-dificultad, aventura o narración pueden variar) que dará respuesta a las necesidades o a los deseos.

La publicidad pondrá en juego las dos posibilidades del objeto (las dos fórmulas para convencer al sujeto). Si los deseos son considerados por el su-

${ }^{31}$ La obra de los Antipublicidad es recuperada por la Publicidad. Los rompeanuncios enseñan a crear anuncios aún más sorprendentes, tal vez más eficaces. 
jeto como necesidades, la referencia la establece con relación a su cuerpo práctico, a la «naturaleza». El objeto, cuyas características y posibilidades prácticas serán idealizadas - superlativo, hipérbole - , aunque marcado por el signo de la precariedad (objeto de consumo, que en el consumo se agota) favorece la dicha, pues colma la «falta» que enuncia la necesidad y significa la alegría de la posesión. Con buenos lebreles y azores mudados la caza no sólo será posible, será una aventura exitosa. Con el robot de cocina, el ama de casa preparará sin esfuerzo platos exquisitos, recibirá la ayuda material que le hará la vida más fácil y tendrá éxito.

Pero si los deseos del sujeto se ven desde la otra perspectiva, con relación a su cuerpo simbólico, con relación a la «cultura», al orden social, los objetos van más allá de la idealización; ya no sólo se exagerarán sus cualidades, se convertirán en fetiches. Su estrecha relación con los mitos revelará su vocación de decir el gozo y se convertirán en objetos de culto. Los magníficos caballos de batalla, las espadas consagradas, las pieles suntuosas, las joyas, los azores mudados, satisfacen el deseo de sentirse diferente, superior, elegido; satisfacen la seguridad de pertenecer a un «orden», de formar parte del mito, de crear los mitos.

La otra variante del paradigma del don que quiero comentar en la publicidad contemporánea encuentra también su equivalente en la literatura medieval. Se trata del don contraignant, don obligado y don sorpresa. El ejemplo más acabado en la publicidad actual es el del «regalo envoltorio». Un anuncio centrado en las etiquetas, en el «papel de regalo», metonimia que ofrece lo abstracto por lo concreto, sin descubrir los objetos ${ }^{32}$.

Con el don contraignant se revaloriza el ritual del don. El regalo es por principio superlativo, un excedente, pues todas las posibilidades están abiertas y durante un tiempo «todo» es posible.

En los romans de Chrétien de Troyes, el don contraignant funciona como un mecanismo de estructuración de la novela; se propone como un enigma y facilita la creación del suspense. Un personaje de la clase caballeresca solicita a otro un don (este segundo personaje pertenecerá a la misma clase social que el primero o a un nivel superior; entre ambos existe una relación feu-

${ }^{32}$ Luis Sánchez Corral (1991) ofrece un ejemplo de anuncio de la marca LOEWE. Una mano ofrece un regalo, un paquete, decorado con un lazo, sobre el que únicamente figura el logotipo de la marca. Un texto simple, arriba, a la derecha de la imagen reza: «Con el corazón en la mano», metáfora que descifra la metonimia sin revelar el contenido concreto del regalo. Metáfora que aprovecha el paradigma de la intención y de la amistad en el don. 
dal de vasallaje. La práctica del don se entiende como un privilegio de clase y como un signo de valor) sin revelarle de qué se trata, sin darle explicación sobre el contenido. Una vez que el interlocutor acepta la concesión del don, se enuncian sus características y condiciones, y ante éstas nadie podrá oponer resistencia, pues la palabra ya ha sido dada ${ }^{33}$.

Lo que cuenta es el rito, el carácter simbólico y social del don más que el contenido, la calidad o la cantidad de ese don. El don obliga, y de alguna manera quien lo solicita considera que lo merece, que le es debido, que él «lo vale». La naturaleza del don se revelará sorprendente, hiperbólica o peligrosa. Decir sí a un don aún no revelado tiene el significado de una entrega de poder sin concesiones, de una entrega total, total largesse, total confianza ${ }^{34}$. Un soberano debe «fiarse» de sus caballeros. Con la práctica del don contraignant, Chrétien de Troyes soluciona un problema de economía novelesca y al mismo tiempo trasmite con metáforas concretas que es necesario y beneficioso para la sociedad, entregar el poder a los caballeros. Este es el objeto de la propaganda que se le ha confiado.

La práctica del don en la publicidad se incluye frecuentemente en campañas de intriga o teaser. A pequeña escala, el suspense funciona en el anuncio como en un relato. Se fragmenta y se dosifica la información (anuncios por episodios que corresponderían a los diferentes capítulos en que puede articularse una historia) o se esconde momentáneamente la identidad del producto o de la marca. Y una vez que se ha captado la atención del receptor se provoca su seguimiento, se le arrastra hasta el desenlace (el interés del receptor aumenta progresivamente hasta que logra entender el significado total). Se crea la expectativa en un primer momento para después engrandecer la aparición del producto (se prepara su apoteosis). Algo semejante hacía Chrétien de Troyes cuando escondía el nombre de sus héroes e iba imponiendo pistas y pruebas para que finalmente el lector y el héroe llegaran a una merecida identificación.

El don sorpresa funciona como un interrogante creativo, como un instrumento de persuasión. Se maquilla como una búsqueda de distinción, de di-

${ }_{33}$ El mismo motivo da inicio a las aventuras en La Muerte de Arturo, de Sir Thomas Malory, donde funcionará como un esquema narrativo recurrente (siglo XV), y seguirá siendo productivo en la narrativa posterior.

34 Según Philippe Breton, la manipulación es una comunicación contraignante. El encuadre contraignant es una estrategia destinada a engañar al interlocutor que funciona en dos tiempos: «consiste à obtenir de l'auditoire un consentement sur une opinion, ou l'adoption d'un comportement qui ne pose aucun problème d'acceptation. Mais l'acceptation de cette opinion va servir de point d'appui efficace pour faire accepter une seconde opinion (celle qui importe au manipulateur)» (Ph. Breton, 2000: 117). 
ferenciación, y pretende hacer partícipe al receptor del mensaje (consumidor del producto), haciéndole ver que es él quien descubre, quien concluye el mensaje. Se le hace sentir protagonista de la aventura, pero aunque las posibilidades parezcan abiertas, se nos dirige siempre en la dirección adecuada a la compra.

La retórica en la publicidad, como en la ficción, intenta descubrir maneras nuevas para picar el interés de la gente, y para mantenerlo. Se quiere lograr el diálogo suscitando el suspense, provocando el misterio, generando la curiosidad, los interrogantes. El don contraignant es una manera de relanzar un relato. Revelarlo supone vivir y sobre todo contar la aventura. El don contraignant, como el objeto sorpresa en la publicidad, otorga continuidad al mensaje propuesto.

El texto de un anuncio de Canal + en la televisión francesa (campaña 2005), propone el enunciado siguiente:

\section{Canal + , demandez plus à la télé.}

Es evidente que además de jugar con el extrañamiento lingüístico de la figura retórica, utiliza el paradigma cultural de la práctica del don. Demandez, en imperativo, nos propone la petición como un derecho, y el don como una necesidad y como una obligación ${ }^{35}$. El adverbio de cantidad (plus = «más») no dice nada; el don no está especificado, y lo dice todo, nos prepara para imaginar posibilidades increíbles, grandes, asombrosas. Manteniendo la incógnita nos promete lo excepcional, lo extraordinario, como en los roman, como en los cuentos o en los sueños; nos propone dar respuesta a nuestros deseos.

El motivo del «don sorpresa» puede contribuir a la eficacia de un anuncio.

Paul Kaye se preguntó cómo escribir un anuncio eficaz. Y respondió: «Prueba esto: ¡Hola!, quiero contarte algo importante, o interesante, o útil, o divertido. Es acerca de ti. No tardaré mucho y hay un premio si estás atento hasta el final». En pocas líneas proponía todos los tópicos retóricos para un buen exordio novelesco: pedir permiso para dirigirse al receptor, despertar expectativas, proponer una finalidad apelando al interlocutor como público

35 Las oraciones exhortativas o imperativas (función apelativa) predominan en el lenguaje de la publicidad: «un hablante francamente dominante emite órdenes categóricas, terminantes, y el atento oyente a quien molestaría un trato tan autoritario aún por parte de un ser querido no se siente coaccionado ni reacciona: obedece a un estado de acrítica aquiescencia» (Block de Behar, 1973: 31) . 
objetivo, hacer gala de brevedad y ofrecer una recompensa (el propio anuncio, el mismo relato se presenta como un don merecido y conseguido). Son los tópicos, motivos literarios convencionales que están presentes en los primeros versos de muchos Cantares de Gesta, y los que conforman y estructuran los comienzos de la novelas de Chrétien de Troyes.

La publicidad recupera los esquemas de la ficción y utiliza los paradigmas que ésta ha mantenido y explotado. Entre todos ellos, el ritual del don es sólo una fórmula que se ha repetido con insistencia, que ha demostrado su eficacia. Hoy, además de hablar de una teología podemos hablar de una sintaxis y de un humanismo, pues la caridad quizás ya no tiene patronos en los cielos. El esquema es fundamentalmente el mismo. El don tiene todavía el significado simbólico que tenía en las sociedades primitivas: es expresión de poder, de fuerza, de libertad y de nobleza; es la salida civilizada, pacífica, de las agresiones, los conflictos, las angustias; consigue lavar la culpa del egoísmo, de la codicia. La publicidad nos propone que compremos para que se realicen nuestros sueños (y apela a nuestra psicología), para resolver nuestros conflictos; nos propone que compremos para ser dueños de nuestra vida, y nos dice (apelando a la teología o al humanismo) que comprando damos, que somos padrinos, patronos liberales que contribuimos al bienestar de otros, al desarrollo, a la alegría, porque parte de nuestro gasto les es destinado, automáticamente, como «beneficio». Y para nosotros, el contra-don es la euforia de la culpa «redimida» o compensada, sublimada (¿religión o psicología?) ${ }^{36}$. Los anuncios reconducen nuestra intención para provocar mejor la compra. Y la paradoja es que siendo liberales no somos libres porque por convención, religión o costumbre estamos tan «obligados» como en la Edad Media.

\section{REFERENCIAS BIBLIOGRÁFICAS}

Breton, Ph. (2000). La Parole manipulée. París: La Découverte.

Block de BeHAR, L. (1973). El lenguaje de la publicidad. Buenos Aires: Siglo XXI.

Clavero, B. (1996). La Grâce du don. Anthropologie catholique de l'économie moderne. París: Albin Michel.

\footnotetext{
${ }^{36}$ Campañas publicitarias de las grandes marcas, sobre todo en Navidad, señalan explícitamente la destinación de un tanto por ciento de los beneficios a fines sociales y humanitarios. El lujo no está reñido con la caridad.
} 
Darsy, S. (2005). Le Temps de l'anti-pub. L'empire de la publicité et ceux qui la combattent. Arles: Actes Sud.

Duby, G. (2001). An 1000, An 2000, sur les traces de nos peurs. París: Les Editions Textuel.

GREIMAS, A. J. (1987). Semántica estructural. Investigación metodológica. Madrid: Gredos.

KLein, N. (2001). No logo. El poder de las marcas. Barcelona: Paidós.

KÖHLER, E. (1974). L'Aventure Chevaleresque. Idéal et réalité dans le roman courtois. París: Gallimard.

LÉVI-STRAuss, Cl. (1981). Les structures élémentaires de la parenté. París: Mouton.

LóPEz EIRE, A. (1998). La retórica de la publicidad. Madrid: Arco/Libros.

MiLlet, V. (1988). «Mecenazgo y lenguaje: acerca de la libertad artística». Quimera 82, 46-47.

MurPHY, J. (1986). La retórica en la Edad Media. Historia de la teoría de la retórica de San Agustín hasta el Renacimiento. México: Fondo de Cultura Económica.

SÁnchez CoRRAL, L. (1991). Retórica y sintaxis de la publicidad. Córdoba: Servicio de Publicaciones de la Universidad de Córdoba.

Zumthor, P. (1963). «Poésie médiévale et poésie moderne; continuité et différences». Cahiers du Sud 372, 269-282.

— (1972). Essai de poétique médiévale. París: Seuil. 